\title{
East Mamasa Protected Forest Ecotourism Development Strategy
}

\author{
Manuel August Todingbua ${ }^{1}$, Athler Palalangi $^{2}$, Ferdinand Poli $^{3}$ \\ Management Department, Universitas Kristen Indonesia Paulus, Makassar, Indonesia ${ }^{1,2,3}$ \\ \{manuel_august@ukipaulus.ac.id ${ }^{1}$ \}
}

\begin{abstract}
The Area of Protected Forest Management Unit IX East Mamasa has a very strategic function which is expected to play a role in improving the welfare of the community and also optimally in protecting the water system to ensure the sustainability of the Bakaru Dam in South Sulawesi and West Sulawesi. Ineffective management of forest and forestry resources, and unclear separation between forest management. The method of analysis used a phenomenological qualitative descriptive method with the help of SWOT analysis. The results showed that, it is necessary to optimize the support of the Central and Regional Governments in maintaining and maintaining the potential of forest resources through the development of ecotourism oriented towards sustainability, financial support, geographic, social, cultural and technological accessibility.
\end{abstract}

Keywords: Forest Ecotourism; Development Strategy; Forestry Resources

\section{Introduction}

The area of the East Mamasa Protected Forest Management Unit, which is located in the upstream area of the Mamasa River Basin in the Saddang River Basin, has a very strategic function because in addition to being expected to play a role in improving community welfare through potential non-timber forest products and environmental services, it is also expected to play an optimal role in protection of water systems to ensure the sustainability of the Bakaru Dam, the largest dam, and is one of the determinants of the continuity of the wheels of life in South Sulawesi and West Sulawesi. However, these forest resources from time to time show an increasing trend of degradation, their prevention programs always indicate an increase from year to year, at least in terms of budget. Meanwhile, a number of parties indicated that the communities living around the forest had not moved from their poor condition and had relatively not experienced significant improvement over the past few decades.

Sustainable forest management which is often echoed by many parties, especially those related to the management, management and use or utilization of forest resources, seems to be still at the conception level. Forest managers and users tend to 'agree' to exploit the forest's potential for short-term economic interests. Encroachment and conversion of forest areas for non-forestry purposes as well as illegal logging and / or over cutting has continued in almost all parts of the region, including in West Sulawesi. Meanwhile, those implementing forest rehabilitation activities tend to have a short-term mindset. This condition is exacerbated by the 
ineffective supervision. This problem is a phenomenon of ineffective ecotourism governance which originates from forest resources. Atika, et al added that the importance of planning in developing tourism potential that is owned [1].

Some of the potential that has been managed by the community is waterfalls, which are quite beautiful natural panoramas. However, the obstacle faced is that in general these areas still have access that is difficult to reach because road infrastructure has not yet supported the development of the existing potential, even though this potential has been utilized by the local community as a tourist spot but has not been managed optimally.

\section{Methodology}

The data analysis method used in this research is phenomenological qualitative descriptive method through SWOT analysis. The analysis phase was carried out by collecting information related to the variable of ecotourism development strategies in East Mamasa. The analysis begins by identifying internal factors (strengths and weaknesses) and external factors (opportunities and threats), which is then made in the formulation of strategies.

The determination of informants is carried out through community members who live in the vicinity of the tourist sites and have an important role in the development of ecotourism in the future. The informants in this study were local government, community leaders, religious leaders, traditional leaders and the general public.

Analysis of the map and field survey, Protection Forest Management Unit IX East Mamasa has a fairly wide critical area of 5,626.06 hectares and can be found throughout the Protection Forest Management Unit IX East Mamasa. The largest area of very critical land is found in Tabang District, covering an area of 2,051.23 hectares.

Table 1. Area of Critical Land Based District in the Area of Protection Forest Management Unit IX East Mamasa

\begin{tabular}{|c|c|c|c|c|c|c|}
\hline District & $\begin{array}{l}\text { Rather } \\
\text { Critical } \\
\end{array}$ & Critical & $\begin{array}{c}\text { Critical } \\
\text { Potential }\end{array}$ & $\begin{array}{c}\text { Very } \\
\text { Critical } \\
\end{array}$ & $\begin{array}{c}\text { Non } \\
\text { Critical } \\
\end{array}$ & Grand Total \\
\hline Mamasa & $752 ., 20$ & & 127.11 & & 9.07 & 888.38 \\
\hline Messawa & $3,126.60$ & 1.59 & 172.04 & 765.65 & 56.90 & $4,122.78$ \\
\hline Nosu & $3,574.83$ & 1.54 & 778.44 & 170.15 & $1,022.28$ & $5,547.23$ \\
\hline Pana & $7,412.75$ & & $1,346.63$ & $1,337.61$ & $1,331.95$ & $11,428.95$ \\
\hline Sesena Padang & $2,531.62$ & & 644.05 & 527.17 & 776.51 & $4,479.36$ \\
\hline Sumarorong & $4,335.19$ & 1.79 & 690.74 & 356.79 & 508.30 & $5,892.81$ \\
\hline Tabang & $4,623.78$ & 8.60 & 584.41 & $2,051.23$ & 95.48 & $7,363.50$ \\
\hline Tanduk Kalua & $5,338.19$ & & $1,774.34$ & 328.51 & $2,114.58$ & $9,555.61$ \\
\hline Tawalian & $1,455.74$ & & 168.45 & 75.43 & 105.63 & $1,805.25$ \\
\hline Grand Total & $33,150.89$ & 13.52 & $6,286.20$ & $5,612.54$ & $6,020.72$ & $51,083.87$ \\
\hline
\end{tabular}

\subsection{The Social, Economic and Cultural Conditions of the Community}

Data from the Mamasa District Center for Statistics (2018), the number of people living in the administrative area in the management of the East Mamasa East Protection Forest Management Unit IX is shown in the Table 2. 
Table 2. Comparison of Area and Total Population in the Administrative Area of Protection Forest Management Unit IX East Mamasa

\begin{tabular}{|c|c|c|c|c|c|}
\hline \multirow{2}{*}{ No } & \multirow{2}{*}{ District } & \multirow{2}{*}{ Area $(\mathbf{K m})$} & \multicolumn{2}{|c|}{ Population } & \multirow{2}{*}{ Amoun } \\
\hline & & & Male & Female & \\
\hline 1 & Mamasa & 250,07 & 12,944 & 13,123 & 26,067 \\
\hline 2 & Messawa & 150,88 & 3,915 & 3,549 & 7,464 \\
\hline 3 & Nosu & 113,33 & 2,472 & 2,153 & 4,625 \\
\hline 4 & Pana & 181,27 & 4,653 & 4,410 & 9,063 \\
\hline 5 & Sesenapadang & 152,70 & 4,090 & 4,123 & 8,213 \\
\hline 6 & Sumarorong & 254,00 & 5,437 & 5,386 & 10,823 \\
\hline 7 & Tabang & 304,51 & 3,329 & 2,978 & 6,307 \\
\hline 8 & Tandukalua & 120,85 & 5,839 & 5,880 & 11,719 \\
\hline 9 & Tawalian & 45,99 & 3,830 & 3,966 & 7,796 \\
\hline
\end{tabular}

The number of residents in Mamasa Regency aged 15 years and over who worked during the past week based on their main occupation and gender is presented in the Table 3.

Table 3. Number of Population Aged 15 Years and Over who Worked During the Past Week by Main Employment and Gender in Mamasa Regency

\begin{tabular}{lccc}
\hline \multicolumn{1}{c}{ Mind Job } & Male & Female & Amount \\
\hline Agriculture, Forestry, Hunting, and Fishery & 18,310 & 20,651 & 38,961 \\
Industry Manucture & 1,795 & 1,938 & 3,733 \\
Wholesaler, Retail, Restaurants, and Hotel & 2,477 & 1,722 & 4,199 \\
Public Services & 5,709 & 6,587 & 12,296 \\
Others & 1,109 & 7,85 & 8,959 \\
Total & 29,400 & 38,748 & 68,148 \\
\hline
\end{tabular}

Other jobs as shown in the table above are mining and quarrying, electricity, gas and water, building, transportation, warehousing and communications, finance, insurance, building rental business, land and company services. Furthermore, the percentage of the population aged 7-24 years according to gender, school age group and school participation in Mamasa Regency is shown in the following Table 4.

Table 4. Percentage of Population Aged 7-24 by Gen

\begin{tabular}{ccccc}
\hline \multirow{2}{*}{ Sex of Kinds } & \multirow{2}{*}{ School Groups } & \multicolumn{3}{c}{ Participation Schools } \\
\cline { 3 - 5 } Male & $7-12$ & 1.99 & 96.96 & 1.04 \\
& $13-15$ & 1.53 & 87.69 & 10.78 \\
& $16-18$ & 1.00 & 72.14 & 26.86 \\
& $19-24$ & 0.00 & 21.98 & 78.02 \\
Female & $7-24$ & 1.29 & 74.50 & 24.22 \\
& $7-12$ & 0.00 & 100.00 & 0.00 \\
& $13-15$ & 0.00 & 94.10 & 5.90 \\
& $16-18$ & 3.86 & 74.71 & 21.42 \\
& $19-24$ & 0.73 & 27.60 & 71.67 \\
& $7-24$ & 0.88 & 74.66 & 24.46 \\
\hline
\end{tabular}

Source: Data from the Central Bureau of Statistics of Mamasa Regency (2018) 


\subsection{Facilities and Infrastructure}

The area of Protection Forest Management Unit IX East Mamasa covers 9 Sub-Districts of the Mamasa District Government Administration Area, which until now is a developing area. As a result, the supporting facilities and infrastructure in developing ecotourism are inadequate. Road infrastructure to most of the East Mamasa Protection Forest Management Unit IX areas such as Pana 'District, Nosu District, Tabang District and several villages in Sumarorong and Messawa Districts at certain times are difficult to reach. The land transportation facilities used are two-wheeled vehicles and four-wheeled vehicles (4WD). Likewise, the existing facilities and infrastructure at the tourist sites are inadequate. In fact, there are several tourist objects that have not been touched by development at all.

\section{Results and Discussion}

\subsection{Internal factors}

The local wisdom of the Mamasa community that has been, is being and will continue to grow and develop in their lives will be a strength in the development of ecotourism. The values that are meant to be inherent in all aspects of life include:

a. Ada' Tuo; namely values that contain a moral agreement to build local wisdom that comes from custom with an emphasis on upholding a broad range of life including humans, animals and plants.

b. Mesa 'Kada Dipotuo Pantan Kada Dipomate; namely values that contain moral agreement in building unity and preventing divisions in society (united we are determined to divorce we collapse).

The community around the research location is also able to socialize well, this is evidenced by the initial research visit which immediately received a good and friendly welcome and the use of their language, which is generally able to understand Indonesian and the local language (Mamasa language). The results of the interviews that have been carried out, $93.33 \%$ of the people selected as informants feel that they are not disturbed by the arrival of tourists in their area on the grounds that they are able to increase people's income by making transactions for agricultural and plantation products and increasing community income by providing for tourists' needs at owned kiosks local community. $6.67 \%$ feel quite disturbed by the presence of tourists. Tyastity, et al said that one of the strategies in developing tourism is through community-based tourism [2].

The economic aspect is one of the most important aspects of natural resource management, including forest resources. Every activity in managing natural resources is always expected to contribute significantly to economic development or growth, either directly or indirectly. Interviews conducted with informants showed that $76.67 \%$ of the community did not know the boundaries of the area because the boundaries were not clear in the field.

\subsection{Community Education about Ecotourism}

The final target of the forest area development program including ecotourism development is a sustainable forest for a prosperous community. The government's efforts to open up job opportunities and business opportunities are only accompanied by the mobilization of all 
existing capabilities to make optimal and sustainable use of regional potential. In line with that, active participation from all levels of society is needed. Interviews conducted with the community found that $93.33 \%$ of the community's perceptions understand about ecotourism and $6.67 \%$ do not understand about ecotourism activities. The low level of education of the people living in and around forest areas has no impact on their understanding of ecotourism. Ahmad Effendi, et al said that the education owned by the tour manager as an independent variable has an influence on the economic value of tourism services [3].The community's understanding of the ecotourism program contributes to increased income, such as kiosk businesses, garden products and livestock that will be easily sold. The importance of empowering and strengthening community capacity for the development of tourist areas has an impact on the development of tourist areas [4], [5]. Ahyak, said that the professionalism of tourism business actors can provid influence on tourism services [6]. It is hoped that in the future the management and utilization of tourism resources will actually be one of the foundations for the realization of human resources who are intelligent and prosperous, and who have concern for the importance of tourism development.

\subsection{Lack of Support for Facilities and Infrastructure}

Inadequate facilities and infrastructure to support ecotourism development cannot be separated from not optimal funding support. Observations in several areas of Protection Forest Management Unit IX East Mamasa which are potential for large-scale ecotourism development such as in Sarambu Malute, Kariango Village, Tawalian District, are currently only managed by local communities. Yensy et al added that the supporting infrastructure greatly influences the development of ecotourism in an area [4].

There is no road infrastructure development for access to the location as well as the construction of infrastructure and other supporting facilities for the operation of these tourist objects. Access to the area which is a path that has existed for a long time and the cleaning is carried out by the surrounding community. Another case of tourism objects in Sarambu Liawan, Tadisi Village, Sumarorong Subdistrict, although they are equipped with supporting infrastructure and facilities, they are not yet adequate, including existing road infrastructure as access to these tourism objects, often people complain about being narrow and have begun to damage. Zakaria said that the provision of supporting facilities and facilities through the spatial concept can support tourism development [7].

Likewise, spots to enjoy beautiful and enchanting natural panoramas such as in Pana District and Tabang District have not been managed because there is no financial support. Access to these areas is difficult due to inadequate road infrastructure. According to Pampang Pasau 'who is the community managing Sarambu Malute, Kariango Village, Tawalian Subdistrict, expressed his hope: "If possible there is a good road to the Sarambu Malute location so that many visitors will come". Furthermore, the former Head of the Tana Toraja Regency Forestry and Plantation Service, Johannes Bataragoa, stated that: "Apart from infrastructure development, in developing ecotourism the government must prepare a nursery which will become a source of seedlings whose management involves the community around the location of tourism objects. The prepared seeds are productive plants and are loved by the community. Planting is adjusted to the rainy season so that growth is optimal".

\subsection{External Factors}


The tourism sector is increasingly developing and government policies are increasingly interested in finding sources of development financing and improving people's welfare, one of which is the development of the tourism industry which in addition to developing regional economic diversification is also in the context of regional development. Head of Planning and Forest Utilization Section of the East Mamasa Protection Forest Management Unit IX, Semuel Sude said: "The tendency of the community now is to use their free time with family for recreation".

The development of science and information technology is an opportunity to encourage tourism growth both in increasing tourist visits which will have a direct impact on increasing the income of the community around tourism objects, regional and even state revenue. The use of science and information technology through tourism promotion to describe tourism products such as: tourist attractions, supporting facilities in services, accessibility and conditions of local communities will greatly encourage the growth and development of the tourism industry. The effectiveness of online media greatly influences the completeness of information for tourists [8], [9].

Table 5. Sources of Visitor Information on Natural Tourism Objects

\begin{tabular}{ccc}
\hline No. & Informan Chategories & Prosentase Responden (\%) \\
\hline 1 & Print Media (newspaper, brosure, etc.) & 6.67 \\
2 & Electronic media (TV, Radio, Internet) & 80 \\
3 & Other Information (Families, friends, etc.) & 13.33 \\
\hline
\end{tabular}

Furthermore, Semuel Sude said that: "The government's support is only limited to regulation and has not yet reached the implementation stage. As a result, the tourism sector, which is the icon of Mamasa Regency, has not optimally contributed to the local government. The role of all stakeholders involved in developing this potential needs to be improved". Furthermore, Palalunan who is a Forestry Extension Officer said that: "The tourism potential in Mamasa Regency is great but there is no seriousness from the district government, village government or the community to develop tourism".

\subsection{Threats}

The increasing need for agricultural land and settlements threatens the existence of forest areas. Table 6 describes the classification of people living around tourist objects in forest areas.

Table 6. Classification of Respondents Based on Where They Live in Forest Areas

\begin{tabular}{cccc}
\hline No & Public Clasification & Amount (man) & Percentage (\%) \\
\hline 1 & Inside Area & 22 & 73.33 \\
2 & Outside Area & 8 & 26.67 \\
\hline
\end{tabular}

According to the Head of the Section for Forest Protection, KSDAE and Community Empowerment at Protection Forest Management Unit IX East Mamasa, Oktopianus: "Community activities in forest areas are clearing areas for agriculture, forest areas used as grazing areas or other activities such as burning forests, polluting soil, water and air ". Maman Chatamallah (2008), adds that the importance of the role of local governments in developing tourism products.

Forest management means the utilization of forest resources to fulfill various human needs in an optimum and sustainable manner. Problems that arise in the implementation of forest 
management tend to become more and more complicated in line with the development of human civilization followed by an increase in human needs, both in quantity and in type and quality, including needs that come from forests. The large number and rate of population growth, an increase in the poverty rate, especially in forest communities and the large number of unemployed people, have further increased the unilateral recognition of forest areas.

As a result, the diversity and productivity of forest ecosystems are lower as a result of the increased intensity of forest use to produce wood and the occurrence of malpractices in forest management. Oktopianus further said: "The unilateral recognition of the area is based on the fact that from generation to generation the location has been inhabited by their ancestors and is an old village. They have long been farming in that location".

\subsection{SWOT Analysis of Ecotourism Development at Protection Forest Management Unit IX East Mamasa}

In selecting and determining the Key Success Factors, or Key Success Factors (FKS), 3 things are calculated, namely Factor weight (BF), Benefit or Support Value (ND), and the Average Linkage Value (NRK). The Support Value multiplied by the Factor Weight will become the Support Weight Value (NBD), while the Linkage Average Value multiplied by the Factor Weight will become the Associated Weight Value. Finally, the Support Weight Value added to the Associated Weight Value will get the Total Weight Value (TNB).

Factor weight calculation is done by comparing the urgency level of each other factor. The calculation is carried out in a factor urgency matrix. The key success factors (FKS) are grouped into internal factors and external factors. If one of the factors is considered more urgent than other factors in its influence on performance achievement, the more urgent factor column is written the letter code which becomes the more urgent factor number. And so on, then add up. The sum of the importance value for each factor is then added up as the weight divider. The sum of the urgency value of each factor if divided by the total number of all factors for each group of driving and inhibiting forces, if multiplied by $100 \%$, the value of the Factor Weight (BF) will be obtained.

Table 7. Matrix of Internal and External Factor (BF) Urgency Weight

\begin{tabular}{|c|c|c|c|c|c|c|c|c|c|}
\hline \multirow{2}{*}{ No } & \multirow{2}{*}{ Internal Factors } & \multicolumn{6}{|c|}{ Urgently Factors } & \multirow{2}{*}{ Amount } & \multirow{2}{*}{ Score } \\
\hline & & $\mathbf{A}$ & B & $\mathbf{C}$ & D & $\mathbf{E}$ & $\mathbf{F}$ & & \\
\hline \multicolumn{10}{|c|}{ Strengths } \\
\hline 1 & Great Potential of Forest Resources & $\mathrm{X}$ & A & A & $\mathrm{D}$ & A & $\mathrm{F}$ & 3 & $3 / 15 \times 100=20$ \\
\hline 2 & Socio-cultural conditions of the community & A & $\mathrm{X}$ & $\mathrm{B}$ & $\mathrm{B}$ & $\mathrm{B}$ & $\mathrm{B}$ & 4 & $4 / 15 \times 100=26,67$ \\
\hline 3 & Availability of planning documents & A & $\mathrm{B}$ & $\mathrm{X}$ & $\mathrm{C}$ & $\mathrm{C}$ & $\mathrm{F}$ & 2 & $2 / 15 \times 100=13,33$ \\
\hline \multicolumn{10}{|c|}{ Weaknesses } \\
\hline 1 & The forest area is not yet established & $\mathrm{D}$ & $\mathrm{B}$ & $\mathrm{C}$ & $\mathrm{X}$ & $\mathrm{E}$ & $\mathrm{F}$ & 1 & $1 / 15 \times 100=6,67$ \\
\hline 2 & $\begin{array}{l}\text { Low community knowledge about } \\
\text { ecotourism }\end{array}$ & $\mathrm{A}$ & $\mathrm{B}$ & $\mathrm{C}$ & $\mathrm{E}$ & $\mathrm{X}$ & $\mathrm{F}$ & 1 & $1 / 15 \times 100=6,67$ \\
\hline 3 & Limited financial support & $\mathrm{F}$ & $\mathrm{B}$ & $\mathrm{F}$ & $\mathrm{F}$ & $\mathrm{F}$ & $\mathrm{X}$ & 4 & $4 / 15 \times 100=26,67$ \\
\hline \multicolumn{10}{|c|}{ Opportunities } \\
\hline 1 & $\begin{array}{l}\text { The tourism sector is growing and } \\
\text { increasingly in demand }\end{array}$ & $\mathrm{X}$ & $\mathrm{B}$ & A & $\mathrm{D}$ & $\mathrm{E}$ & A & 2 & $2 / 15 \times 100=13,33$ \\
\hline 2 & $\begin{array}{l}\text { There is support from the Government and } \\
\text { Local Government }\end{array}$ & $\mathrm{B}$ & $X$ & $\mathrm{~B}$ & $\mathrm{~B}$ & $\mathrm{~B}$ & B & 5 & $5 / 15 \times 100=33,33$ \\
\hline
\end{tabular}




\begin{tabular}{|c|c|c|c|c|c|c|c|c|c|}
\hline \multirow[b]{2}{*}{ No } & \multirow{2}{*}{ Internal Factors } & \multicolumn{6}{|c|}{ Urgently Factors } & \multirow{2}{*}{ Amount } & \multirow{2}{*}{ Score } \\
\hline & & $\mathbf{A}$ & B & $\mathrm{C}$ & D & $\mathbf{E}$ & $\mathbf{F}$ & & \\
\hline 3 & $\begin{array}{l}\text { The rapid development of Science and } \\
\text { Information Technology }\end{array}$ & $\mathrm{A}$ & B & $\mathrm{X}$ & $\mathrm{D}$ & $\mathrm{E}$ & $\mathrm{C}$ & 1 & $1 / 15 \times 100=6,67$ \\
\hline \multicolumn{10}{|c|}{ Threats } \\
\hline 1 & $\begin{array}{l}\text { The increasing need for agricultural } \\
\text { land and settlements threatens the } \\
\text { existence of forest areas }\end{array}$ & $\mathrm{D}$ & B & D & $\mathrm{X}$ & $\mathrm{E}$ & $\mathrm{D}$ & 3 & $3 / 15 \times 100=20$ \\
\hline 2 & $\begin{array}{l}\text { Community activities in forest areas } \\
\text { that will threaten flora and fauna } \\
\text { diversity as well as potential } \\
\text { environmental services }\end{array}$ & $\mathrm{E}$ & B & $\mathrm{E}$ & $\mathrm{E}$ & $\mathrm{X}$ & $\mathrm{F}$ & 3 & $3 / 15 \times 100=20$ \\
\hline 3 & Unilateral recognition of forest areas & A & B & $\mathrm{C}$ & $\mathrm{D}$ & $\mathrm{F}$ & $\mathrm{X}$ & 4 & $1 / 15 \times 100=6,67$ \\
\hline
\end{tabular}

\subsection{Support Value Calculation}

Each factor or work element has the potential to be an organization's superiority in achieving greater success. Each factor is actually an input that must be managed properly in order to provide special or maximum support so that it becomes superior in achieving greater success. For this reason, each factor is assessed for its support in achieving organizational goals. The support rating for each factor is measured on a scale of 1 to 5 as follows:

a. The number 1 shows the value of support is very small

b. The number 2 shows the value of support immensely

c. The number 3 shows the value of support is sufficient

d. The number 4 indicates the value of a large support

e. The number 5 shows the value of support is very large

Table 8. Value of Support for Internal and External Factors

\begin{tabular}{|c|c|c|}
\hline No & Internal and External Factors & $\begin{array}{l}\text { Value of } \\
\text { Support }\end{array}$ \\
\hline \multicolumn{3}{|c|}{ Strengths } \\
\hline 1 & Great Potential of Forest Resources & 5 \\
\hline 2 & Socio-cultural conditions of the community & 4 \\
\hline 3 & Availability of planning documents & 3 \\
\hline \multicolumn{3}{|c|}{ Weaknesses } \\
\hline 1 & The forest area is not yet established & 5 \\
\hline 2 & Low community knowledge about ecotourism & 3 \\
\hline 3 & Limited financial support & 4 \\
\hline \multicolumn{3}{|c|}{ Opportunities } \\
\hline 1 & The tourism sector is growing and increasingly in demand & 4 \\
\hline 2 & There is support from the Government and Local Government & 5 \\
\hline 3 & The rapid development of Science and Information Technology & 3 \\
\hline \multicolumn{3}{|c|}{ Threats } \\
\hline 1 & $\begin{array}{l}\text { The increasing need for agricultural land and settlements threatens } \\
\text { the existence of forest areas }\end{array}$ & 5 \\
\hline 2 & Community activities in forest areas that will threaten flora and fauna & 4 \\
\hline
\end{tabular}




\subsection{Calculation of the Average Value of Linkage}

The relationship between one factor and another must be seen. In achieving the indicators of the targets that have been set, the presence of one factor with another is a favorable condition for achieving the target, so these two factors will form a synergistic relationship that tends to be more profitable if compared to the presence of each factor itself. If two factors, one beneficial factor, and one detrimental factor in achieving the target, there can be a mutually neutralizing relationship. And if the two factors present are detrimental, then their presence will be even more detrimental in achieving the target. The level of relationship is then assessed with a scale of values as follows:
a. The number 0 indicates there is no association value
b. Number 1 shows that the relationship value is very small
c. Number 2 shows a small association value
d. Number 3 shows that the value of the relationship is sufficient
e. Number 4 shows the value of a large association
f. Number 5 shows that the value of the relationship is very large

Table 9. Value of Relationship between Internal and External Factors

\begin{tabular}{|c|c|c|c|c|c|c|c|c|c|c|c|c|c|c|c|}
\hline \multirow{2}{*}{ No } & \multirow{2}{*}{$\begin{array}{c}\text { Internal and } \\
\text { External Factors }\end{array}$} & \multicolumn{12}{|c|}{ Value of Relationship } & \multirow{2}{*}{ TNB } & \multirow{2}{*}{ NRK } \\
\hline & & 1 & 2 & 3 & 4 & 5 & 6 & 7 & 8 & 9 & 10 & 11 & 12 & & \\
\hline \multicolumn{16}{|c|}{ Strengths } \\
\hline 1 & $\begin{array}{l}\text { Great Potential of } \\
\text { Forest Resources }\end{array}$ & $\mathrm{X}$ & 5 & 4 & 5 & 3 & 4 & 4 & 5 & 4 & 5 & 4 & 3 & 46 & 4.18 \\
\hline 2 & $\begin{array}{l}\text { Socio-cultural } \\
\text { conditions } \\
\text { of the community }\end{array}$ & 5 & $\mathrm{X}$ & 3 & 4 & 5 & 3 & 4 & 4 & 2 & 4 & 4 & 3 & 41 & 3.73 \\
\hline 3 & $\begin{array}{l}\text { Availability of planning } \\
\text { documents }\end{array}$ & 4 & 3 & X & 3 & 1 & 3 & 4 & 5 & 4 & 1 & 1 & 1 & 30 & 2.73 \\
\hline \multicolumn{16}{|c|}{ Weaknesses } \\
\hline 1 & $\begin{array}{l}\text { The forest area is } \\
\text { not yet established }\end{array}$ & 5 & 4 & 3 & X & 3 & 5 & 3 & 5 & 4 & 5 & 5 & 5 & 47 & 4.27 \\
\hline 2 & $\begin{array}{l}\text { Low community } \\
\text { knowledge about } \\
\text { ecotourism }\end{array}$ & 3 & 5 & 1 & 3 & $\mathrm{X}$ & 3 & 5 & 2 & 3 & 3 & 3 & 3 & 34 & 3.09 \\
\hline 3 & $\begin{array}{l}\text { Limited financial } \\
\text { support }\end{array}$ & 4 & 3 & 3 & 5 & 3 & $\mathrm{X}$ & 4 & 4 & 3 & 4 & 4 & 3 & 40 & 3.64 \\
\hline \multicolumn{16}{|c|}{ Opportunities } \\
\hline 1 & $\begin{array}{l}\text { The tourism sector is } \\
\text { growing and } \\
\text { increasingly } \\
\text { in demand }\end{array}$ & 4 & 4 & 4 & 3 & 5 & 4 & $\mathrm{X}$ & 5 & 5 & 4 & 4 & 2 & 44 & 4.00 \\
\hline 2 & $\begin{array}{l}\text { There is support from } \\
\text { the Government and } \\
\text { Local Government }\end{array}$ & 5 & 4 & 5 & 5 & 2 & 4 & 5 & $\mathrm{X}$ & 2 & 4 & 4 & 2 & 42 & 3.82 \\
\hline 3 & $\begin{array}{l}\text { The rapid development } \\
\text { of Science and } \\
\text { Information Technology }\end{array}$ & 4 & 2 & 4 & 4 & 3 & 3 & 5 & 2 & $\mathrm{X}$ & 2 & 2 & 2 & 33 & 3.00 \\
\hline
\end{tabular}


1 The increasing need

$\begin{array}{llllllllllllll}5 & 4 & 1 & 5 & 3 & 4 & 4 & 4 & 2 & X & 5 & 5 & 42 & 3.82\end{array}$ for agricultural land and settlements threatens the existence of forest areas

2 Community activities in forest areas that will threaten flora and fauna diversity as well as potential environmental services

3 Unilateral recognition of forest areas

\subsection{Selection of Key Success Factors}

In order to determine a number of strengths which will become the basic strategy and follow-up plans, it is necessary to further analyze the areas of strength that will be changed and which differ in the desired circumstances. In analyzing some of these strengths it is necessary to pay attention to the following matters:

a. The key strengths are selected based on the largest TNB.

b. If TNB is the same, then choose the largest NBD.

c. If the NBD is the same, choose the largest NBK.

d. If the NBK is the same, then choose the biggest BF.

e. If the BF is the same, it is chosen based on the author's consideration.

f. If the NBK is the same, then choose the largest BF.

$\mathrm{g}$. If the $\mathrm{BF}$ is the same, it is chosen based on the author's consideration

Table 10. Key Success Factors

\begin{tabular}{|c|c|c|c|c|c|c|c|c|}
\hline No. & $\begin{array}{c}\text { Internal and } \\
\text { External Factors }\end{array}$ & $\begin{array}{c}\text { Score of } \\
\text { Factors } \\
\quad(\%)\end{array}$ & ND & $\begin{array}{c}\text { NBD } \\
\text { (BFxND) }\end{array}$ & NRK & $\begin{array}{c}\text { NBK } \\
(\text { BFXNRK) }\end{array}$ & $\begin{array}{c}\text { TNB } \\
(\mathbf{N B D}+\mathbf{N B K})\end{array}$ & FKS \\
\hline \multicolumn{9}{|c|}{ Strengths } \\
\hline 1 & $\begin{array}{l}\text { Great Potential of Forest } \\
\text { Resources }\end{array}$ & 20.00 & 5 & 1.00 & 4.18 & 0.84 & 1.84 & II \\
\hline 2 & $\begin{array}{l}\text { Socio-cultural conditions } \\
\text { of the community }\end{array}$ & 26.67 & 4 & 1.07 & 3.73 & 0.99 & 2.06 & I \\
\hline 3 & $\begin{array}{l}\text { Availability of } \\
\text { planning documents }\end{array}$ & 13.33 & 3 & 0.40 & 2.73 & 0.18 & 0.58 & III \\
\hline & & & & & & & 4.48 & \\
\hline \multicolumn{9}{|c|}{ Weaknesses } \\
\hline 1 & $\begin{array}{l}\text { The forest area is not yet } \\
\text { established }\end{array}$ & 6.67 & 5 & 0.33 & 4.27 & 0.28 & 0.61 & II \\
\hline 2 & $\begin{array}{l}\text { Low community knowledge } \\
\text { about ecotourism }\end{array}$ & 6.67 & 3 & 0.20 & 3.09 & 0.21 & 0.41 & III \\
\hline 3 & Limited financial support & 26.67 & 4 & 1.06 & 3.64 & 0.97 & $\begin{array}{l}2.03 \\
3.05\end{array}$ & I \\
\hline \multicolumn{9}{|c|}{ Opportunities } \\
\hline 1 & $\begin{array}{l}\text { The tourism sector is growing } \\
\text { and increasingly in demand }\end{array}$ & 13.33 & 4 & 0.53 & 4.00 & 0.53 & 1.06 & II \\
\hline
\end{tabular}


2 There is support from the Government and Local Government

3 The rapid development of Science and Information Technology

\section{Threats}

1 The increasing need for settlements threatens the existence of forest areas

2 Community activities in forest areas that will threaten flora and fauna diversity as well as potential

environmental services

3 Unilateral recognition of forest areas agricultural land and

\begin{tabular}{|c|c|c|c|c|c|}
\hline 33.33 & 5 & 1.67 & 3.82 & 1.27 & 2.94 \\
\hline \multirow[t]{2}{*}{6.67} & 3 & 0.20 & 3.00 & 0.20 & 0.40 \\
\hline & & & & & 4.40 \\
\hline 20.00 & 5 & 1.00 & 3.82 & 0.76 & 1.76 \\
\hline 20.00 & 4 & 0.80 & 3.73 & 0.75 & 1.55 \\
\hline 6.67 & 3 & 0.20 & 3.09 & 0.21 & 0.41 \\
\hline & & & & & 3.72 \\
\hline
\end{tabular}

With the aforementioned assessment, eight main strengths were selected as the basis for the strategy in planning further activities. Furthermore, the key strengths chosen are two strengths, two opportunities, two weaknesses and two threats; for more details, it can be stated as follows : Table 8 shows that the highest value of strength is the socio-cultural conditions of the community (2.06), the highest value of weakness is the lack of financial support (2.03), the highest opportunity value is the support of the government and local government $(2,94)$ and then the highest threat value is the increasing need for agricultural land and settlements which will threaten the existence of forest areas $(1,76)$. To show the key factors (organizational strength map) by adding the TNB scores on the strengths, weaknesses, opportunities and threats that exist.

\subsection{Organizational Strength Map}

The value of the threat factor weight (3.72) is obtained on the y-axis value (0.68). So that the organizational strength field (Internal and External Factors) which is the key to success is the interaction pattern of each factor which is formulated as follows in the following figure 1.

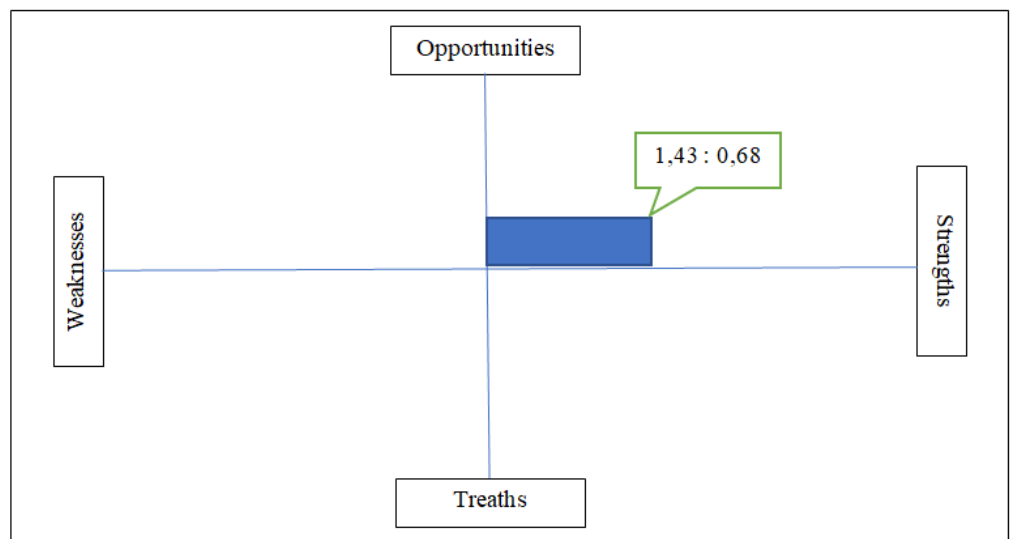

Fig. 1. Organizational Strength Map 
The formulation of the Ecotourism Development Strategy at Protection Forest Management Unit IX East Mamasa can be seen in Table 10. The results of the SWOT analysis in Table 10 show that the recommendations for the Ecotourism Development Strategy in the Protected Forest Management Unit IX East Mamasa are as follows:

\section{a) Strategic Strength - Opportunities (SO)}

Ecotourism management by optimizing the support of the Government and Local Government as well as the socio-cultural conditions of the community in managing the great potential of forest resources in developing ecotourism which is currently developing and in demand. The government as the regulator must provide maximum space for community participation in managing the potential of existing forest resources based on local wisdom. The partnership pattern between the government, investors and the community will further accelerate the achievement of ecotourism development so that a management can be realized that can increase community income through opening up job opportunities and increasing contributions to the center and regions. Supervision of ecotourism management will play an important role in order to maintain the principle of sustainability.

\section{b) Weaknesses Strategy - Opportunities (WO)}

Optimizing the support of the Government and Local Governments in efforts to stabilize forest areas because the potential for forest resources in Protection Forest Management Unit IX is very large and if managed properly will contribute to development. The participation of the community through participatory area boundaries will be very important in the effort to recognize the boundaries of these areas together so that there is no longer a view in the community that the government limits the space for them to meet their needs. In addition, the pattern of forest management must be socialized and understood together that in a protected forest area there should be no activities other than the use of the area, the use of non-timber forest products and environmental services that can be carried out after a permit from the government is obtained. Tourism development through ecotourism programs is an appropriate forest management strategy in improving community welfare and forest conservation.

\section{c) Strenght Strategy - Threats (ST)}

The increasing need for land outside forestry interests such as agricultural land and settlements will be a threat to the existence of forest areas. In addition, community activities in forest areas in the form of encroachment and fires will threaten flora and fauna diversity as well as the potential for environmental services. Optimizing the socio-cultural conditions of the community in managing the large potential of forest resources can be done through the social forestry program which is regulated in the Minister of Environment and Forestry Regulation Number: P.83 / MENLHK / SETJEN / KUM.1 /10/2016.

\section{d) Weaknesses Strategy - Threats (WT)}

In Fiscal Year 2018, Protection Forest Management Unit IX East Mamasa has built 2 units of Resort Forest Management Offices (RPH). In order to operationalize the RPH Office several personnel have been assigned. Increasing the role and function of RPH as a site level 
management unit in carrying out guidance, counseling and coordination with stakeholders to prevent control and encroachment of forest areas must be a concern in preventing community activities that damage and even threaten the existence of forest areas and the diversity of flora and fauna as well as potential environmental services. Role and function This is done through preemptive and preventive efforts and even through repressive measures in the framework of enforcing laws and regulations.

\subsection{Ecotourism Development Strategy at Protection Forest Management Unit IX East Mamasa}

The results of the SWOT analysis and the Organizational Strength Map, the Ecotourism Development Strategy at Protection Forest Management Unit IX in East Mamasa is to take advantage of the interaction pattern of strengths and opportunities as follows:

a. Optimizing the support of the government and local governments in maintaining and maintaining the potential of forest resources optimally in supporting the development of ecotourism with an emphasis on sustainability. Revitalization of forest area boundaries, especially those areas that have been encroached by local residents must be carried out immediately. In addition, the socialization of area boundaries is to provide understanding to the community about the responsibility of each community member to participate in efforts to safeguard forest areas and the legal consequences for any party encroaching or exploiting forest areas illegally.

b. Optimizing the support of the Government and Regional Governments in the development of better accessibility which is able to free regions from geographic, social, cultural and technological isolation.

c. Optimizing the socio-cultural conditions of the community in an effort to develop ecologybased tourism based on sustainable principles by taking into account environmental sustainability and community empowerment. Community groups that have been dependent on forest resources for their livelihoods need to be granted access to forest management through social forestry so that all potential non-timber forest products can be managed optimally and sustainably in increasing the diversity of non-timber forest products. Hijriati, et al said Changes felt by the community in ecological and social aspects with the existence of community-based ecotourism activities [10]. Management of environmental services that reflects the culture and local wisdom of the community will be a special attraction for tourists. Development of social forestry with the main target in the area around the forest area border with settlements. This is not only intended to support efforts to supervise / secure forest areas (by the community involved), but also to increase the income and welfare of community members who live around the forest. The development of the potential of forest resources always takes into account the aspirations of the community and has their feet on regional culture and oriented towards the realization of a better community life materially and spiritually, with an emphasis on the harmonization of social life. Ecotourism development based on sustainable principles by paying attention to environmental sustainability and community empowerment.

d. Optimizing government and local government support in setting regulations and funding support for ecotourism development. According to Ely Sambominanga (member of the Mamasa Regional People's Representative Assembly). "Encouraging the birth of a regional regulation to become a legal umbrella for ecotourism development. Mamasa is referred to as a tourism destination in West Sulawesi Province, especially natural tourism and cultural 
tourism so that future tourism development is ecology-based tourism or often called ecotourism".

e. Utilizing electronic media in promoting the potential of ecotourism in Protection Forest Management UnitIX East Mamasa. According to Witasari, Anna and Mulyonohadi, Bambang that: "Digital marketing is a marketing strategy to promote a brand using digital media that can reach consumers in a timely, personal and relevant manner".

\section{Conclusion}

Discussion of the results of identification and analysis of literature study data, observations and interviews from both respondents, visitors and managers, it can be concluded:

a. Key factors that determine success include:

Internal factors, there are the following strengths: Community socio-cultural conditions, large potential forest resources. In addition, there are the following weaknesses: Lack of financial support, not yet established forest areas.

External factors, there are opportunities as follows: Support from the Government and Local Governments, the Tourism Sector is Growing and Increasingly Interested. In addition, there are threats as follows: Increased need for agricultural land and settlements so that it threatens the existence of forest areas, Community activities in forest areas that will threaten diversity of flora and fauna and potential environmental services.

b. By paying attention to the organizational strength map, the Ecotourism Development at Protection Forest Management Unit IX East Mamasa in quadrant 1 is a very favorable situation. Organizations have strengths and opportunities, so a strategy that can be implemented is to support aggressive policies.

\section{References}

[1] Atika, Rizky Salsabila Ivabianca Putri, Elizabeth Puspaningrum Sinyor, and Annusha Chandrika Putri, "Village Tourism Potential Development Strategy Swot Analysis Based On The Village Of Sidomekar And Use Of The District Online Tour Guide Application Jember", 3rd National Seminar on Management and Business, Management Study Program, Faculty of Economics and Business, University of Jember, 2018.

[2] Tyastity, Fiqriena Anggun and Yustisia Pasfatima Mbulu, "Community Based Culinary Tourism Development Strategy in Rungkut Surabaya" vol. 7, no.1, Juni 2019,

[3] Effendi, Ahmad, Samsul Bakri, and Rusita, "Economic Value of Tangkil Island Tourism Services, Lampung Province with the Travel Cost Method Approach", Sylva Lestari Journal, vol. 3, no. 3, pp. 71-84, 2015.

[4] Yensy L. Salamor, Debby V. Pattimahu, and Semmy Limba, "Study of Ecotourism Management Based on Economy and Social: Case Study of the Nusaniwe Peninsula, Ambon City", DOI:10.30598/jhppk.2017.1.3.275, 2018.

[5] Salim,Tamrin, Risma Illa Maulany, and Roland A Barkey, "Tongke-Tongke Mangrove Ecotourism Development Strategy in Sinjai Wedding Tourism Marketing Strategy as an Alternative Destination", Forest and Public Journal, vol. 10, no. 2, pp. 268-282, 2018. 
[6] Ahyak, "Halal Management Strategy for Surabaya City Tourism (Study on Religious Tourism in Sunan Ampel Surabaya)", Pascasarjana Universitas Islam Negeri Sunan Ampel Surabaya, 2018.

[7] Zakaria, Faris, and Rima Dewi Suprihardjo, "The Concept of Development of a Tourism Village Area in Bandungan Village, Pakong District, Pamekasan Regency”, Journal of Pomits Technical, vol. 3, no.2, 2014.

[8] Adhanisa, Chikameirani and Anna Fatchiya, "The Effectiveness Of Websites And Instagram As A Means Of Promoting Community-Based Tourism Areas," Communication Science and Public Development Journal, vol. 1, no. 4, pp. 451-466, 2017.

[9] Chatamallah, Maman, "Public Relations Strategy in Tourism Promotion: Case Study with Marketing Public Relations Approach in Banten Province", Mediator Journal, vol. 9, no. 2, 2008.

[10] Hijriati, Emma and Rina Mardiana, "The Effect of Community-Based Ecotourism on Changing Ecological, Social and Economic Conditions at Batusuhunan Village, Sukabumi”, Sosiologi Pedesaan Journal, vol. 2, no. 3, 2014. 